\title{
SEBARAN INTENSITAS CAHAYA PADA BAGAN TANCAP DI PERAIRAN PANTAI KEPULAUAN SERIBU
}

\author{
Erfind Nurdin dan Hufiadi \\ Peneliti pada Balai Riset Perikanan Laut, Muara Baru-Jakarta \\ Teregistrasi I tanggal: 13 Mei 2008; Diterima setelah perbaikan tanggal: 11 September 2008; \\ Disetujui terbit tanggal: 13 April 2009
}

\begin{abstract}
ABSTRAK
Penggunaan intensitas cahaya pada unit penangkapan bagan cenderung meningkat dari waktu ke'waktu. Hal ini didasari pada persepsi nelayan bahwa intensitas cahaya yang tinggi akan meningkatkan hasil tangkapan. Penelitian dilaksanakan di perairan Pulau Lancang (Kepulauan Seribu) pada bulan Mei 2005 dengan tujuan untuk mengetahui rentang intensitas cahaya serta tingkah laku ikan di bawah pengaruh cahaya. Penelitian dilakukan melalui pengamatan dan pengukuran nilai intensitas cahaya dengan meggunakan quantum meter LI COR $250\left(\mu \mathrm{mol} \mathrm{s}^{-1} \mathrm{~m}^{-2}\right)$ pada jenis lampu yang berbeda, dan digunakan pula echosounder Simrad EY 500 untuk memperoleh data sebaran kelompok ikan. Keberadaan ikan lebih banyak ditemukan pada lahan transisi perbatasan antara light zone dan dark zone dengan nilai intensitas kurang dari $0,01 \mu \mathrm{mol} \mathrm{s} \mathrm{s}^{-1} \mathrm{~m}^{-2}$. Nilai panjang ikan (FL) tangkapan didominansi oleh ukuran kecil $(-70-50 \mathrm{db})$, dengan modus tertinggi pada nilai FL (fork Length) lebih kecil dari nilai Lm (length at maturity). Hasil ini menandakan bahwa ukuran ikan tersebut belum layak tangkap.
\end{abstract}

KATA KUNCl: bagan tancap, intensitas cahaya, lampu mercuri, petromak

ABSTRACT: Distribution of light intensity on fixed bamboo liftnet in coastal waters of Seribu Island. By: Erfind Nurdin and Hufiadi

The use of light intensity on fixed bamboo lift net (bagan) tends to increase by time. Fishermen believe that the intensity always increases linearly with the catch. This research was conducted on May 2005 in Lancang Island (Seribu Islands). The aim of this study are to know the range of light intensity used and the behaviour of fish under the light influence. LI COR 250 Quantum meter $\left(\mu \mathrm{mol} \mathrm{s}^{-1} \mathrm{~m}^{-2}\right)$ for light intensity at different lamps amount and Simrad EY 500 scientific echosounder was utilized to obtain the data of fish school around fixed. The fish school was found in high quantity at the transition area between light and dark zones with intensity value at less than $0.01 \mu \mathrm{mol} \mathrm{s} \mathrm{s}^{-1} \mathrm{~m}^{2}$. The fork length of captured fish was dominated by small fish (-70--50 db), with the highest modus fork length smaller than the length at maturity. This means that the size of fish is not feasible to be caught.

\section{KEYWORDS: fixed bamboo liftnet, light intensity, mercury lamp, kerosene pressure lamp}

\section{PENDAHULUAN}

Metode penangkapan ikan yang menggunakan alat bantu cahaya di dalam pengoperasiannya diistilahkan sebagai perikanan cahaya (light fishing). Alat tangkap ini merupakan salah satu teknologi penangkapan yang dianggap sukses dan mengalami perkembangan yang pesat (Arimoto, 1999). Berdasarkan pada cara pengoperasiannya, bagan dimasukan ke dalam kelompok alat tangkap lift net (jaring angkat), tetapi karena menggunakan lampu sebagai alat untuk menarik perhatian ikan, maka dapat juga dikelompokan ke dalam light fishing (Subani \& Barus, 1989). Menurut Ayodhyoa (1981), peristiwa berkumpulnya ikan di bawah sumber cahaya disebabkan karena adanya sifat fototaksis positif dan makanan.
Bagan merupakan salah satu jenis alat tangkap yang telah lama dikenal masyarakat Indonesia. Dalam perkembangannya bagan dibedakan menjadi 2 jenis yaitu bagan tancap (fixed lift net) yang beroperasi pada kedalaman 5-10 m dan bagan apung atau bagan perahu (floated lift net) yang dapat berpindah (Baskoro, 1999). Sumber cahaya yang digunakan pada perikanan bagan bervariasi mulai dari lampu petromak, lampu dop, serta lampu fluorocent dengan daya 250-puluhan ribuan watt seperti pada kasus bagan rambo di perairan Sulawesi Selatan (Sudirman, 2003).

Tipe alat tangkap yang menggunakan alat bantu cahaya pada umumnya dioperasikan untuk menangkap jenis ikan yang termasuk kelompok ikan pelagis. Terkait dengan penggunaan alat bantu 
cahaya, adalah suatu kenyataan bahwa pada tataran praktisi lapangan (pengusaha dan nelayan) terdapat kecenderungan adanya penggunaan intensitas cahaya yang semakin besar dalam operasi penangkapan berbagai jenis alat tangkap. Kebanyakan orang beranggapan bahwa semakin besar intensitas cahaya lampu yang dipakai, maka akan semakin banyak hasil tangkapan ikan yang diperoleh.

Kegiatan (preliminary research) ini bertujuan untuk memperoleh informasi dasar kegiatan penangkapan yang menggunakan bagan tancap dengan jenis sumber cahaya yang berbeda dengan tekanan pada:

1. Pengukuran sebaran cahaya secara vertikal dan horisontal.

2. Pengamatan pola pengelompokan ikan di bawah pengaruh cahaya lampu.

3. Komposisi hasil tangkapan (jenis dan ukuran spesies dominan).

\section{BAHAN DAN METODE}

Penelitian dilakukan pada tanggal 13-19 Mei 2005 di Pulau Lancang (Kepulauan Seribu) pada posisi $5^{\circ} 56^{\prime} 26^{\prime \prime} \mathrm{S}$ atau $106^{\circ} 35^{\prime} 20^{\prime \prime} \mathrm{E}$. Pengamatan dilakukan 2 kali ulangan untuk tiap jenis lampu mercury 1.000 watt (1 unit) dan petromak (10 unit) dengan lama penyinaran 10 jam.

Pengamatan lampu mercury 1.000 watt dan petromak 10 unit dilakukan karena banyak nelayan yang menggunakannya dengan anggapan semakin besar daya dan banyaknya jumiah lampu yang dipakai, maka hasil tangkapan akan semakin bertambah.

\section{Alat dan Bahan}

1. Bagan bambu ukuran panjang $12 \mathrm{~m}$, lebar $12 \mathrm{~m}$, dan tinggi $21 \mathrm{~m}$.

2. Perahu kayu panjang $12 \mathrm{~m}$, lebar $2,6 \mathrm{~m}$, dan dalam $1 \mathrm{~m}$.

3. Lampu petromak dan mercuri.

4. LI-250 light meter (quantum meter).

5. Simrad EY 500 (akustik).

6. GPS.

7. Alat ukur bobot (timbangan).

8. Alat ukur panjang (meteran)

9. Pelampung bola plastik diameter $12 \mathrm{~cm}$.

10. Alat ukur kuat arus (stopwatch).

11. Sechi disk.

12. Buku identifikasi FAO, (Carpenter \& Niem, 1998).

\section{Pengumpulan Data}

Pengukuran intensitas cahaya yang dilakukan mencakup sebaran mendatar (horisontal) dan vertikal berdasarkan pada kedalaman. Data sebaran intensitas cahaya di kolom perairan diukur dengan menggunakan Photometer LICOR LI-250 dengan satuan $\mu \mathrm{mol} \mathrm{s}{ }^{-1} \mathrm{~m}^{-2}$. Sebaran nilai intensitas cahaya secara horisontal dan vertikal diperoleh dengan mengukur mulai dari pusat atau sumber cahaya dan bergerak menjauhi sumber cahaya pada setiap jarak $1 \mathrm{~m}$ sampai dengan diperoleh nilai cahaya mendekati atau sama dengan nol.

Pengumpulan data sebaran gerombolan ikan dilakukan dengan menggunakan Portable Scientific Echosounder SIMRAD EY 500 dengan tranduser Split Beam Acoustic System yang berfrekuensi $38 \mathrm{kHz}$ dan dilengkapi dengan 1 unit komputer untuk merekam data yang diperoleh dari Echosounder. Data akustik direkam secara terus-menerus dalam hard disk komputer. Data yang diperoleh di lapangan berupa data gram kemudian diubah menjadi data threshold. Perolehan data akustik dilakukan dengan metode pengintegrasian echo secara terus-menerus dengan menggunakan target strength threshold $-70 \mathrm{~dB}$ dan SV threshold -80 dB, dengan interval TS $-3 \mathrm{~dB}$.

Pengamatan sebaran ikan pada alat tangkap bagan dilakukan dengan 2 pendekatan; pertama dilakukan dengan metode tetap (statis) di atas bagan dengan sistem tranduser digantung pada posisi tepat di bawah lampu. Pengamatan ini bertujuan untuk mengetahui pola pengelompokan ikan di bawah cahaya terhadap lamanya periode penyinaran cahaya.

Pengamatan kedua dilakukan secara spiral dengan mengitari perairan di sekitar bagan, ini bertujuan untuk mengetahui seberapa jauh pengaruh cahaya terhadap pengerombolan ikan di sekitar bagan. Pengamatan dilakukan dengan menggunakan perahu, tranduser dipasang pada sisi kiri perahu dengan sistem side mounted. Bentuk trek yang digunakan pada pengamatan ini adalah bentuk spiral, sebagai titik awal untuk perekaman data akustik adalah titik terdekat dengan bagan, kemudian makin menjauhi bagan sampai dengan jarak tertentu di mana intensitas cahaya diperkirakan sudah lemah.

Perekaman data akustik dilakukan berbasis pada posisi geografi (GPS) dan waktu, data jumlah sasaran disimpan secara simultan dengan data waktu dan posisi geografis kapal. Data ini diolah dengan cara ping to ping analysis. 
Pengukuran kuat arus permukaan air laut menggunakan pelampung bola yang diikat pada seutas tali dan stopwatch untuk mencatat lama waktu yang dibutuhkan, sedangkan kecerahan diukur dengan sechi disk. Pengukuran terhadap panjang bobot ikan hasil tangkapan dilakukan menggunakan timbangan dan measuring paper. Identifikasi jenis ikan hasil tangkapan menggunakan buku FAO Species Identification Guide for Fishery Purposes (Carpenter \& Niem, 1998).

\section{Analisis Data}

Analisis intensitas cahaya dari hasil pengukuran besaran nilai yang tercatat pada photometerdilakukan secara deskriptif dengan tampilan grafik yang dianalisis menggunakan software MS-Excel. Sedangkan analisis akustik menggunakan software SHOW, di mana setiap titik contoh data akan menghasilkan satu unit data sasaran. Data sasaran tunggal diintegrasikan untuk mendapatkan nilai densitas dan besaran ikan dugaan berdasarkan pada nilai target strength dari sasaran. Integrasi echo dilakukan berdasarkan pada teori echo integratoryang sudah baku yang terdapat pada software EP 500. Data hasil keluaran dari software SHOW dan EP 500 berupa data dalam format ASCII. Data keluaran ini selanjutnya diolah dengan menggunakan program sederhana yang dibuat dengan fasilitas yang tersedia dalam bahasa pemrograman BASIC dan ditabulasi dengan spreadsheet excel. Analisis lanjutan dilakukan secara deskriptif dengan tampilan grafik dengan menggunakan software MS-Exceldan surfer.

\section{HASIL DAN BAHASAN}

\section{Pengukuran Intensitas Cahaya}

Hasil pengukuran di lapangan menunjukkan bahwa kuat arus di sekitar bagan rata-rata mencapai $3,45 \mathrm{~m}$ per menit dengan arah arus yang berlainan setiap harinya dan kecerahan di sekitar bagan rata-rata mencapai $3,7 \mathrm{~m}$.

Sebaran cahaya dalam kolom air dengan lampu mercury 1.000 watt dan 10 unit petromak secara umum memiliki pola yang hampir sama (Gambar 1 dan 2 ). Intensitas cahaya lampu mercury 1.000 watt secara horisontal pada permukaan perairan mencapai $0,004 \mu \mathrm{mol} \mathrm{s}^{-1} \mathrm{~m}^{-2}$ pada jarak $10 \mathrm{~m}$ dari pusat cahaya dan secara vertikal pada pusat cahaya intensitas mencapai $0,002 \mu \mathrm{mol} \mathrm{s}^{-1} \mathrm{~m}^{-2}$ pada kedalaman $10 \mathrm{~m}$. Intensitas cahaya petromak 10 lampu secara horisontal pada permukaan perairan mencapai 0,014 $\mu \mathrm{mol} \mathrm{s} \mathrm{s}^{-1} \mathrm{~m}^{-2}$ pada jarak $6 \mathrm{~m}$ dari pusat cahaya dan secara vertikal pada pusat cahaya intensitas mencapai $0,024 \mu \mathrm{mol} \mathrm{s}^{-1} \mathrm{~m}^{-2}$ pada kedalaman $6 \mathrm{~m}$.

Gambar 1 dan 2 menunjukan bahwa sebaran lampu mercuri dengan daya 1.000 watt terdeteksi adanya intensitas cahaya pada jarak $10 \mathrm{~m}$ dari pusat cahaya $0,004 \mu \mathrm{mol} \mathrm{s}^{-1} \mathrm{~m}^{-2}$ (horisontal) dan $0,002 \mu \mathrm{mol}$ $\mathrm{s}^{-1} \mathrm{~m}^{-2}$ (vertikal), sedangkan pada petromak (10 unit) sebaran intensitas cahaya hanya mencapai jarak 6 $\mathrm{m}$ dari pusat cahaya $0,014 \mu \mathrm{mol} \mathrm{s}^{-1} \mathrm{~m}^{-2}$ (horisontal) dan $0,024 \mu \mathrm{mol} \mathrm{s}^{-1} \mathrm{~m}^{-2}$ (vertikal). Berdasarkan pada data sebaran intensitas cahaya yang diperoleh terlihat bahwa besaran daya lampu mercuri dan jumlah lampu petromak berbanding lurus dengan penetrasinya, yaitu semakin besar daya atau jumlah lampu yang digunakan maka akan semakin luas lahan yang dipengaruhi.

Sebaran cahaya dalam kolom air merupakan proses yang kompleks dan dipengaruhi oleh banyak faktor. Di samping nilai intensitas, kecerahan, jumlah partikel terlarut, arus, serta sudut datang cahaya merupakan beberapa hal yang menentukan jangkauan sebaran cahaya. Berdasarkan pada data sebaran intensitas cahaya yang diperoleh selama penelitian

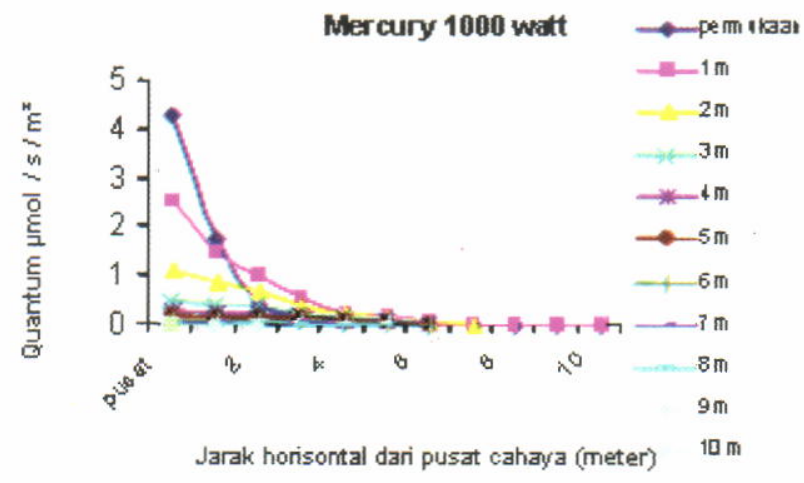

Gambar 1. Sebaran cahaya lampu mercury 1.000 watt.

Figure 1. Light distribution of mercury lamp 1,000 watt. 


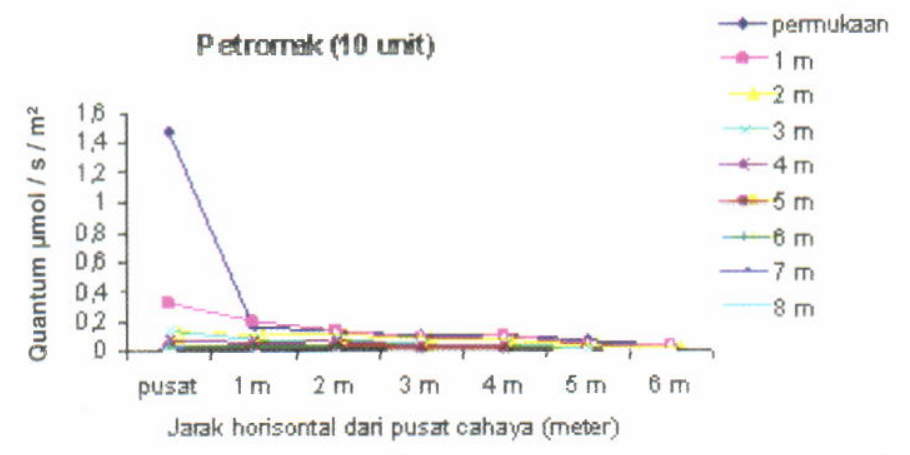

Gambar 2. Sebaran cahaya petromak (10 unit).

Figure 2. Light distribution of kerosene pressured lamp (10 units).

tampak bahwa, besaran daya lampu mercuri dan jumlah lampu petromak berbanding lurus dengan penetrasinya. Semakin besar daya atau jumlah lampu, maka akan semakin luas lahan yang mampu dipengaruhi.

\section{Sebaran Ikan di Sekitar Bagan Tancap}

\section{Stasioner}

\section{10 petromak}

Dari hasil pengukuran didapatkan light zone pada perlakuan ini adalah $8 \mathrm{~m}$. Analisis akustik dilakukan pada strata $8 \mathrm{~m}$ untuk light zone dan 8-16 m untuk mendapatkan gambaran pengelompokan ikan pada dark zone. Dari hasil plot nilai scattering area sasaran di bawah pengaruh cahaya dapat dilihat bahwa pengaruh 10 unit lampu petromak terhadap pengerombolan ikan pada light zone cenderung menurun seiring lamanya penyinaran, selanjutnya ikan-ikan cenderung semakin terkonsentrasi pada sekitar daerah dark zone (Gambar 3).

Variasi nilai scattering area pada perlakuan ini cenderung berbeda. Ikan-ikan yang terdeteksi terpisah menjadi 2 kelompok yaitu kelompok ikan yang cenderung berada di kolom perairan bagian atas dekat dengan sumber cahaya (A) dan kelompok kedua adalah ikan-ikan yang cenderung memilih berada pada dekat dasar perairan (B). Gambar 4 terlihat bahwa sasaran yang mengelompok pada permukaan perairan (light zone) (A) dan terdapat pula mengelompok di dekat dasar perairan (B). Gerombolan ikan yang terlihat pada echogram hasil deteksi untuk perlakuan ini juga memperlihatkan kumpulan-kumpulan sasaran yang relatif kecil antara $-70--50 \mathrm{db}$. Hal ini dapat dibandingkan dengan pengukuran panjang dan bobot ikan dominan hasil tangkapan (lihat Tabel 2), yang menunjukkan bahwa nilai modus fork length lebih rendah dibanding dengan nilai length of maturity.

\section{Lampu Mercuri 1.000 watt}

Pada lampu mercury 1.000 watt nilai light zone yang didapatkan $10 \mathrm{~m}$ baik secara vertikal maupun horisontal. Hal ini berpengaruh terhadap pengelompokan ikan di bawah penyinaran lampu mercury 1.000 watt. Analisis akustik untuk light zone dilakukan pada strata $10 \mathrm{~m}$ dan 10-16 m untuk dark zone.

Variasi nilai scattering area pada light zone juga memiliki kecenderungan meningkat seiring lamanya penyinaran lampu, begitu pula pola yang terdapat pada dark zone, peningkatan secara gradual terlihat pada dark zone (Gambar 5). Gerombolan ikan yang terlihat pada echogram hasil deteksi untuk perlakuan ini juga memperlihatkan kumpulan-kumpulan sasaran yang relatif kecil antara $-70-50 \mathrm{db}$ (Gambar 6).

Perilaku ikan-ikan pada perlakuan lampu mercury 1.000 watt cenderung memiliki pola yang sama dengan lampu petromak 10 unit. Hal ini terjadi diduga karena adanya kelompok ikan dengan spesies yang sama untuk setiap jenis lampu yang digunakan yang disebabkan lokasi penelitian pada habitat yang sama. Semakin lama penyinaran berlangsung, maka konsentrasi gerombolan ikan akan semakin mendekat ke sumber cahaya. Ikan-ikan yang terdeteksi terpisah menjadi 2 kelompok yaitu kelompok ikan yang cenderung berada di kolom perairan bagian atas dekat dengan pusat cahaya (light zone) dan bagian bawah (dark zone) berada pada dekat dasar perairan (Gambar 6). 
Variasi vilai SA target pads light zone

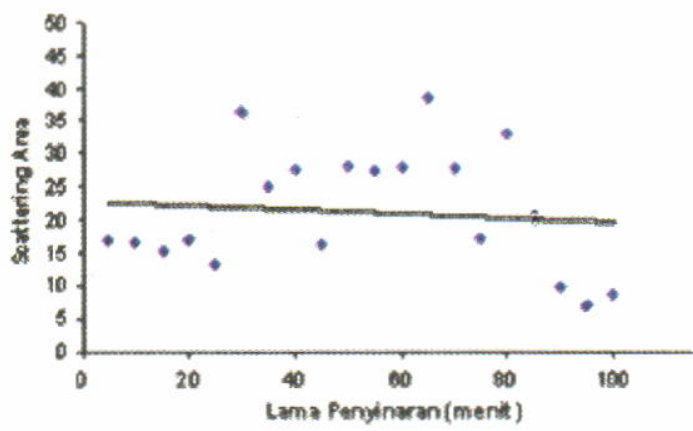

Variasi nilk SA target poch dark zone

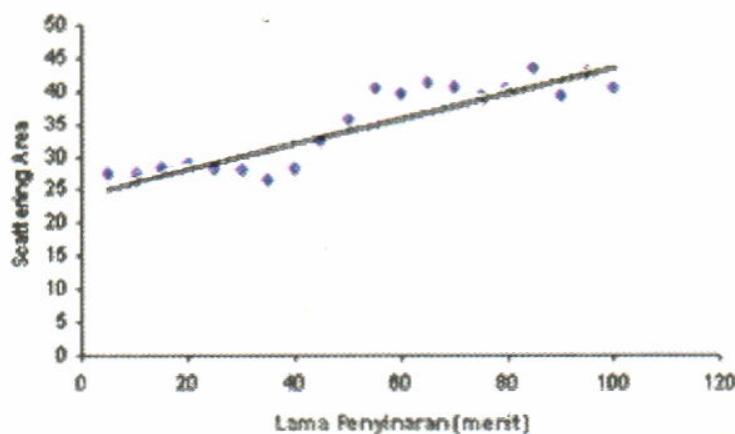

Gambar 3. Variasi nilai scattering area pada lampu petromak (10 unit).

Figure 3. Variation of scattering area value at light distribution of kerosene pressured lamp (10 units).

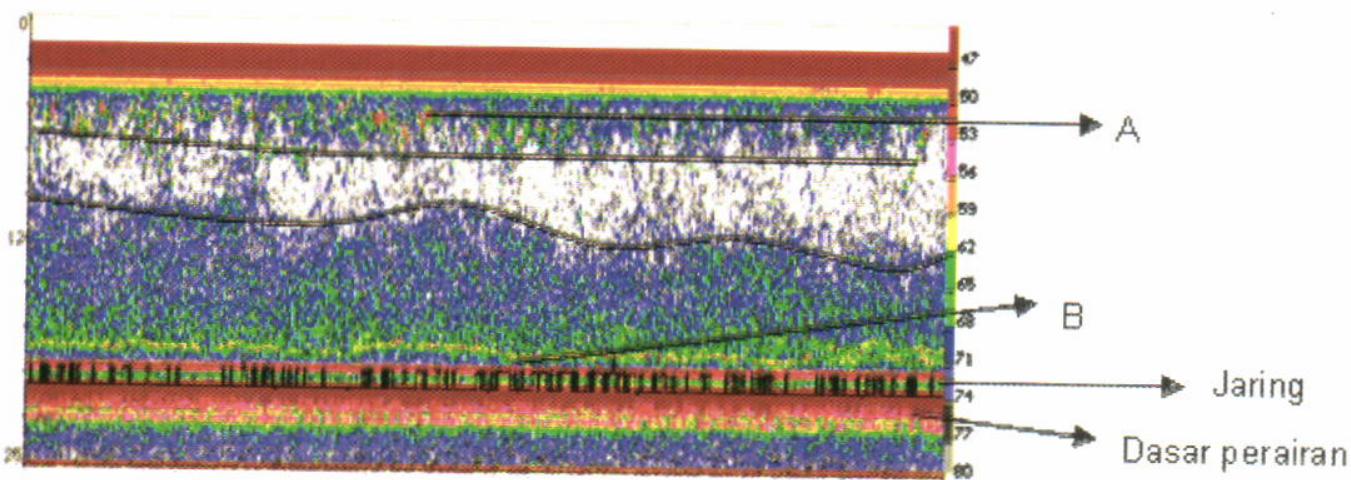

Gambar 4. Echogram lampu 10 unit petromak, (A) kelompok ikan pada daerah terang, (B) kelompok ikan pada daerah gelap.

Figure 4. Echogram of kerosene pressured lamp (10 units), (A) fish scholling in light zone, (B) fish scholling in dark zone.

Variasi nilai sk target pada light zone

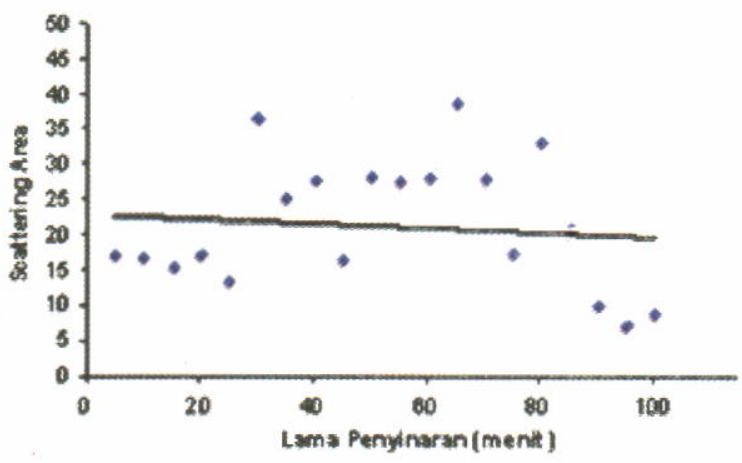

Variasi nibi sa target pach dark zone

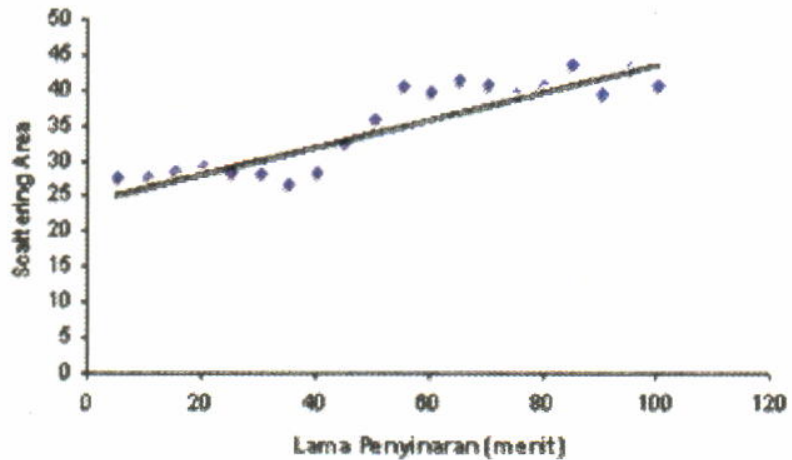

Gambar 5. Variasi nilai scattering area pada perlakuan lampu mercury 1.000 watt.

Figure 5. Variation of scattering area value at light distribution of mercury lamp 1.000 watt. 


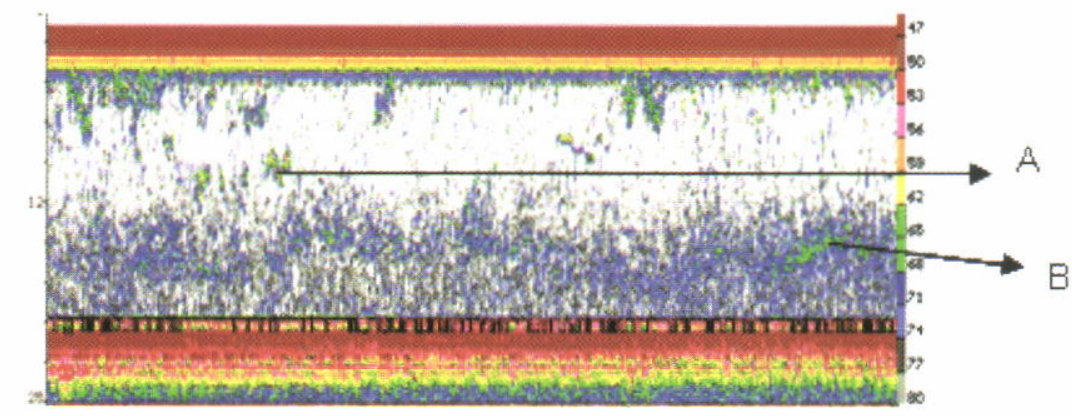

Gambar 6. Echogram lampu mercury 1.000 watt, (A) kelompok ikan pada daerah terang, (B) kelompok ikan pada daerah gelap.

Figure 6. Echogram of mercury lamp 1,000 watt, (A) fish scholling in light zone, (B) fish scholling in dark

\section{Covered(Spiral)}

Luasan cakupan light zone secara horisontal untuk perlakuan 10 petromak adalah daerah dengan jari-jari $6 \mathrm{~m}$, lamanya penyinaran tampak berpengaruh terhadap ikan-ikan yang terdeteksi. Terlihat pada sounding saat waktu penyinaran yang lebih lama lebih banyak sasaran yang terdeteksi dan semakin terkonsentrasi mendekati sumber cahaya. Sasaran terdeteksi sampai dengan jarak $38 \mathrm{~m}$ dari pusat cahaya (Gambar 7).

Luasan cakupan light zone secara horisontal untuk perlakuan lampu mercury 1.000 watt adalah daerah dengan jari-jari $10 \mathrm{~m}$. Terlihat dengan jelas bahwa sasaran-sasaran yang terkonsentarsi di bawah pengaruh cahaya mercurymeningkat dengan cakupan lahan yang lebih luas, sasaran terdeteksi sampai dengan radius $50 \mathrm{~m}$ dari sumber cahaya. Lama penyinaran juga tampak sangat berpengaruh terhadap jumlah sasaran yang terdeteksi di sekitar bagan (Gambar 7).

Menurut Iskandar et al. (2004), peningkatan jumlah ikan yang berkumpul dengan bertambahnya waktu penyinaran diduga terjadi karena adanya mekanisme rantai makanan, di mana ikan-ikan kecil akan merangsang kehadiran predator ke lokasi penangkapan, sehingga meningkatkan jumlah individu di lokasi penangkapan.

Hal ini menunjukkan bahwa semakin lama penyinaran dilakukan, maka kelompok ikan fototaksis positif akan lebih terkonsentrasi pada sumber cahaya, begitu juga plankton dan ikan kecil sebagai makanan yang menimbulkan daya tarik dan perhatian kelompok ikan lain di luar kelompok ikan fototaksis positif yang terkonsentrasi di luar wilayah light zone, sehingga dapat menimbulkan suatu rantai makanan.
Menurut Ayodhyoa (1981), peristiwa berkumpulnya ikan di bawah sumber cahaya disebabkan karena adanya sifat fototaksis positif dan makanan. Atmadja (1994) menjelaskan bahwa ikan berkumpul di sekitar cahaya, karena fototaksis positif serta terkonsentrasinya plankton dan ikan kecil yang menarik perhatian ikan besar sebagai pemangsa. Puspito (2006) mengatakan bahwa keberhasilan penangkapan ikan dengan bagan salah satunya sangat ditentukan oleh intensitas cahaya yang masuk ke dalam kolom perairan, semakin besar intensitas cahaya yang masuk ke dalam kolom perairan, maka diperkirakan semakin besar jumlah ikan yang bersifat fototaksis positif mendatangi bagan.

\section{Hasil Tangkapan}

Hasil tangkapan di lapangan menunjukkan bahwa ikan yang dominan tertangkap adalah jenis ikan pelagis kecil walaupun demikian juga tertangkap beberapa jenis ikan dasar. Untuk lampu mercury 1.000 watt rata-rata hasil tangkapan per setting $22,811 \mathrm{~g}$ dan untuk lampu petromak 10 unit 7,679 g (Tabel 1).

Dari hasil tangkapan yang diperoleh terlihat bahwa komposisi jenis ikan didominansi oleh ikan pelagis kecil $74,55 \%$ dan ikan dasar 25,45\% (Gambar 8 ). Tertangkapnya jenis ikan dasar pada pengoperasian alat tangkap bagan dapat dikarenakan oleh jaring yang digunakan sampai dengan dasar perairan dengan kedalaman $21 \mathrm{~m}$.

Menurut Baskoro et al. (2004), keragaman spesies yang tertangkap saat haulling pada bagan rambo cenderung didominansi oleh jenis ikan pelagis kecil dan moluska, sedangkan ikan demersal bervariasi. $\mathrm{Hal}$ ini dikarenakan ikan-ikan jenis pelagis sudah terbiasa dengan kondisi terang, sedangkan jenis ikan demersal yang tertangkap ditentukan oleh keadaan fishing ground. 

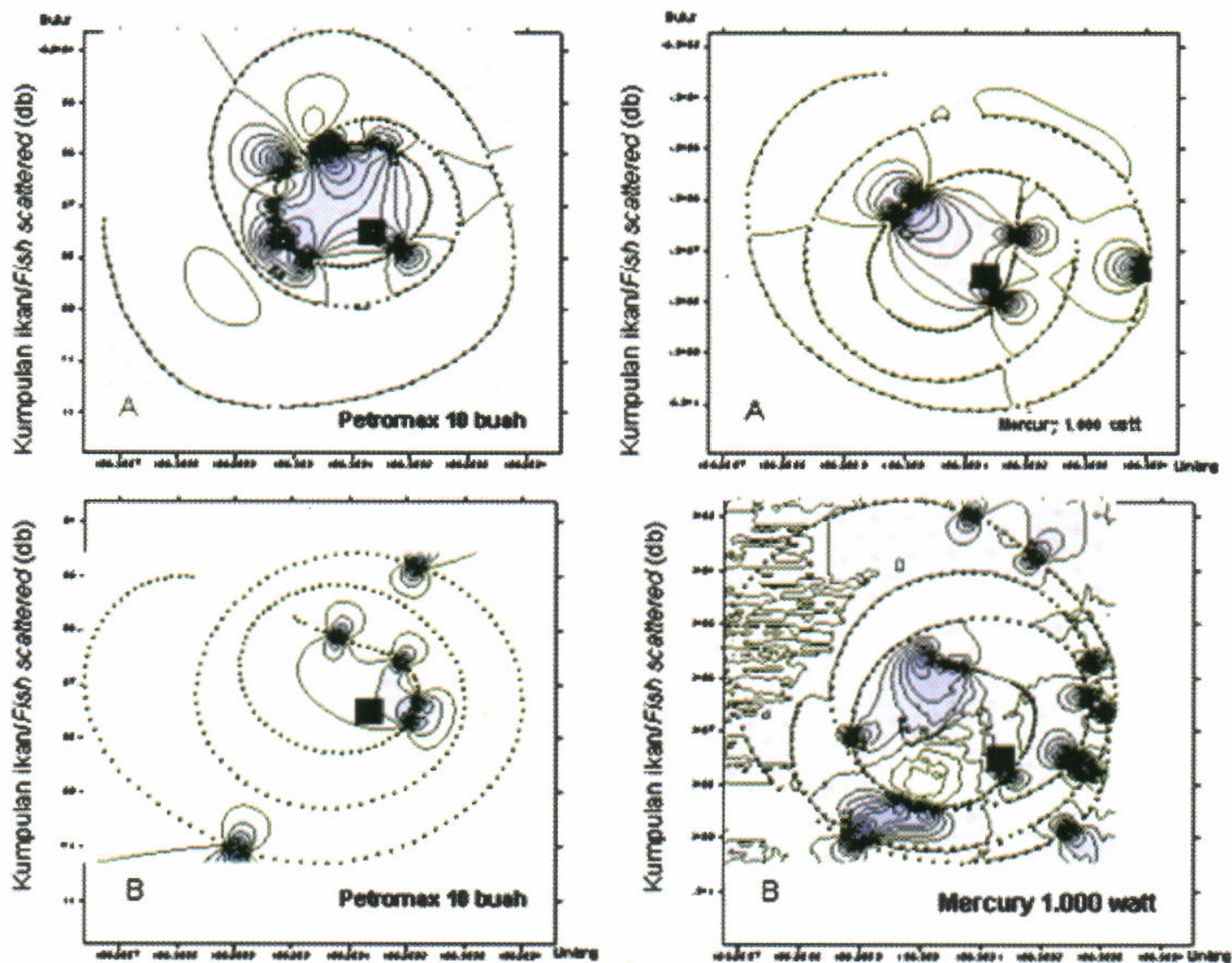

Gambar 7. Hasil pengamatan (A) 4 jam penyinaran dan (B) 8 jam penyinaran.

Figure 7. The observation result ( $A$ ) 4 hours illumination and (B) 8 hours illumination.

Tabel 1. Hasil tangkapan bagan 2 kali ulangan (haulling)

Table 1. Catch of fixed bamboo liftnet in 2 replications (haulling)

\begin{tabular}{lcc}
\hline \multicolumn{1}{c}{ Jenis ikan/Species } & $\begin{array}{c}\text { Mercury Bobot/ } \\
\text { Mercury lamp weight (g) }\end{array}$ & $\begin{array}{c}\text { Petromak Bobot/ } \\
\text { Petromak lamp weight (g) }\end{array}$ \\
\hline Petek (Leiognathus bindus) & $1.2574,0$ & $2.839,7$ \\
Cumi (Loligo sp.) & $1.876,7$ & $2.803,2$ \\
Teri (Stelephorus indicius) & $9.023,0$ & $7.020,0$ \\
Tembang (Sardinella fimbriata) & $7.272,9$ & $1.129,9$ \\
Bentong (Selar crumenophtalmus) & $3.986,4$ & 92,0 \\
Selar kuning (Selaroides leptolepis) & $10.339,2$ & $1.186,6$ \\
Torani (Cypsilurus poecilopterus) & 375,0 & 0,0 \\
Cendro (Tylosurus crocodilus) & 70,0 & 0,0 \\
Kembung (Rastrelliger brachysoma) & 15,0 & 0,0 \\
Baronang (Siganus guttatus) & 90,0 & 16,7 \\
Layur (Trichiurus sp.) & 0,0 & 270,0 \\
Jumlah & $\mathbf{4 5 . 6 2 2 , 2}$ & $\mathbf{1 5 . 3 5 8 , 0}$
\end{tabular}

Jenis hasil tangkapan

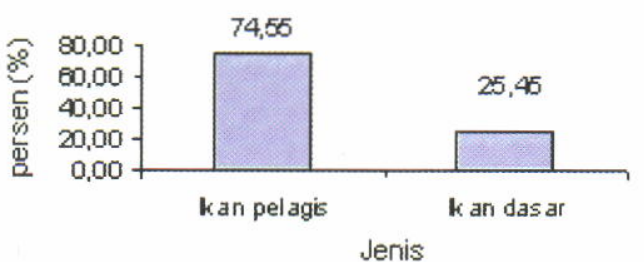

Gambar 8. Komposisi hasil tangkapan.

Figure 8. Catch composition. 


\section{Rerata berat kan dominan}

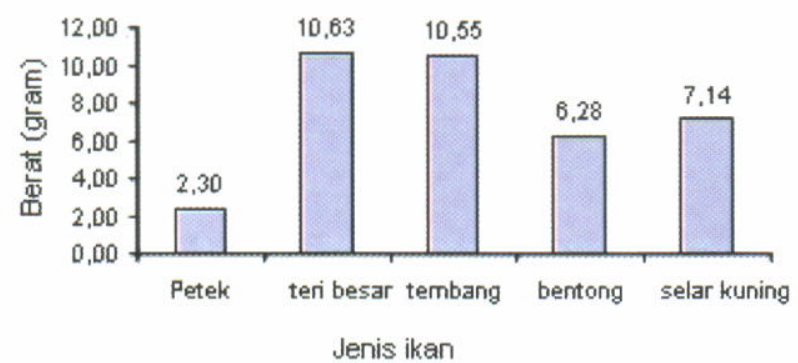

Gambar 9. Rata-rata bobot ikan dominan.

Figure 9. Average weight of dominant fish.

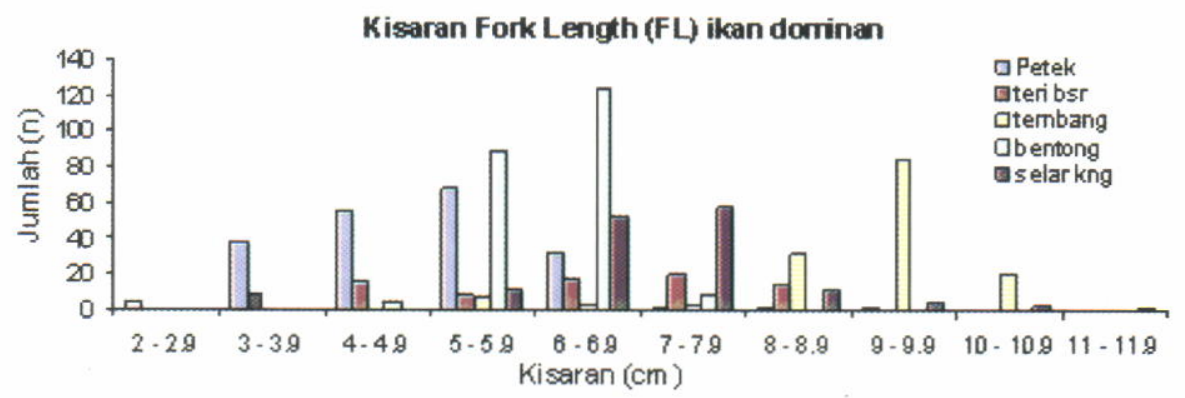

Gambar 10. Kisaran panjang cagak ikan dominant.

Figure 10. Fork length range of dominant fish.

Tabel 2. Kisaran fork length dan length of maturity ikan dominan Table 2. Fork length and length range of maturity of dominant fish

\begin{tabular}{lcccc}
\hline \multicolumn{1}{c}{$\begin{array}{c}\text { Jenis ikan/ } \\
\text { Species }\end{array}$} & $\begin{array}{c}\text { Jumlah/ } \\
\text { Number } \\
\text { (n) }\end{array}$ & $\begin{array}{c}\text { Fork length } \\
\text { (cm) }\end{array}$ & $\begin{array}{c}\text { Modus FL } \\
\text { (cm) }\end{array}$ & $\begin{array}{c}\text { Length of maturity } \\
\text { (cm) }\end{array}$ \\
\hline Teri (Stelephorus indicius) & 80 & $2-9$ & 8 & 12 \\
Petek (Leiognathus splendens) & 196 & $2-10$ & 6 & 9 \\
Tembang (Sardinella fimbriata) & 140 & $5-11$ & 10 & 14 \\
Selar kuning (Selaroides leptolepis) & 145 & $5-14$ & 8 & 23 \\
Bentong (Selar crumenopthalmus) & 226 & $4-8$ & 7 & 19 \\
\hline
\end{tabular}

Pengambilan contoh dilakukan terhadap spesies ikan pelagis yang dominan, ikan teri (Stelephorus indicius) 80 ekor dengan rata-rata bobot 10,63 g, kisaran fork length $2-9 \mathrm{~cm}$. Ikan petek (Leiognathus splendens) 196 ekor dengan rata-rata bobot 2,30 g, kisaran fork length 2-10 cm. Ikan tembang (Sardinella fimbriata) 145 ekor dengan rata-rata bobot 10,55 g, kisaran fork length $5-11 \mathrm{~cm}$. Ikan selar kuning (Selaroides leptolepis) 140 ekor dengan rata-rata bobot 7,14 g, kisaran fork length 5-14 cm. Ikan bentong (Selar crumenopthalmus) 226 ekor dengan rata-rata bobot $6,28 \mathrm{~g}$, kisaran fork length $4-8 \mathrm{~cm}$ (Gambar 9 dan 10).

Dari 5 jenis ikan dominan hasil tangkapan yang berhasil diukur (Tabel 2) dapat dilihat bahwa ukuran modus pada nilai fork length lebih kecil dari nilai length of maturity. Hal ini menandakan bahwa ukuran ikan dominan hasil tangkapan tersebut kecil dan belum layak tangkap.

\section{KESIMPULAN}

1. Intensitas cahaya lampu mercury 1.000 watt secara horisontal pada permukaan perairan mencapai $0,004 \mu \mathrm{mol} \mathrm{s}^{-1} \mathrm{~m}^{-2}$ pada jarak $10 \mathrm{~m}$ dari sumber cahaya dan secara vertikal pada sumber cahaya intensitas mencapai $0,002 \mu \mathrm{mol} \mathrm{s} \mathrm{s}^{-1} \mathrm{~m}^{-2}$ pada kedalaman $10 \mathrm{~m}$.

2. Intensitas cahaya 10 lampu petromak secara horisontal pada permukaan perairan mencapai $0,014 \mu \mathrm{mol} \mathrm{s}^{-1} \mathrm{~m}^{-2}$ pada jarak $6 \mathrm{~m}$ dari sumber 
cahaya dan secara vertikal pada sumber cahaya intensitas mencapai $0,024 \mu \mathrm{mol} \mathrm{s} \mathrm{s}^{-1} \mathrm{~m}^{-2}$ pada kedalaman $6 \mathrm{~m}$.

3. Kelompok ikan secara horisontal dari pusat cahaya terdeteksi pada jarak $38 \mathrm{~m}$ untuk lampu petromak (10 unit) dan $50 \mathrm{~m}$ untuk lampu mercury (1.000 watt).

4. Ukuran ikan didominansi ikan-ikan yang berukuran kecil (-70--50 db), diduga konsentrasi ikan ini berada pada wilayah transisi (transition area) perbatasan antara light zone dan dark zone dengan kekuatan intensitas cahaya kurang dari $0,01 \mu \mathrm{mol} \mathrm{s}^{-1} \mathrm{~m}^{-2}$.

\section{PERSANTUNAN}

Tulisan ini merupakan kontribusi dari kegiatan riset pengaruh intensitas cahaya terhadap pola pengelompokkan ikan pada alat tangkap yang menggunakan alat bantu cahaya di perairan utara Jawa, T. A. 2005, di Balai Riset Perikanan Laut-Muara Baru, Jakarta

\section{DAFTAR PUSTAKA}

Arimoto, T. 1999. Fish Behaviour for Improving Fish Capture Technology. Tokyo University of Fisheries. Japan. $55 \mathrm{pp}$.

Atmadja, S. B. 1994. Pengamatan hasil tangkapan jaring klitik dengan cahaya dan kemungkinan pengembangan pada perikanan skala kecil. Jurnal Penelitian Perikanan Laut. Badan Penelitian dan Pengembangan Pertanian. (87): p. 56-59.

Ayodhyoa. 1981. Metode Penangkapan Ikan. Yayasan Dewi Sri. Bogor. 90 pp.
Baskoro, M. S. 1999. Capture process of the floatedbamboo platform lift net with light attraction (bagan). Doctor Thessis. Graduate School of Fisheries. Tokyo Univ. of Fish. Japan 149 pp.

Baskoro, M. S., Sudirman, \& A. Purbayanto. 2004. Analisis hasil tangkapan dan keragaman spesies setiap waktu haulling pada bagan rambo di perairan Selat Makassar. Buletin PSP. Institut Pertanian Bogor. XIII (1): p. 16-33.

Carpenter, K. E. \& V. H. Niem. 1998, The living marine resources of the western central pacific. Species Identification Guide for Fishery Purposes. FAO. Rome.

Iskandar, M. D., I. W. Ronny, \& Indrajaya. 2004. Respon ikan terhadap cahaya: Studi kasus penangkapan ikan dengan menggunakan bagan motor di perairan Teluk Semangka, Lampung. Buletin PSP. Institut Pertanian Bogor. XIV (2): p. 76-87.

Puspito, G. 2006. Persamaan matematika untuk menentukan sudut kemiringan tudung lampu yang digunakan pada perikanan bagan. Prosiding Seminar Nasional Perikanan Tangkap. Fakultas Perikanan dan IImu Kelautan. Institut Pertanian Bogor. p. 197-210.

Subani, W. \& H. R. Barus. 1989. Alat penangkapan ikan dan udang laut di Indonesia. Jurnal Penelitian Perikanan Laut. No.50 (Special Edition). Balai Penelitian Perikanan Laut. Jakarta. 248 pp.

Sudirman. 2003. Analisis tingkah laku ikan untuk mewujudkan teknologi ramah lingkungan dalam proses penangkapan pada bagan rambo. Disertasi Program Pascasarjana. Institut Pertanian Bogor. $307 \mathrm{pp}$. 